\title{
Authors of Articles and Book Reviews
}

SIARHEI BOHDAN, PhD in Political Science, Ostrogorski Centre, zmysla@, yahoo.com

ULADZIMIR KANANOVICH, visiting scholar, Faculty 'Artes Liberales', University of Warsaw, ukananovich@gmail.com

LIZAVETA KASMACH, PhD in History, independent scholar, kasmach@ ualberta.ca

TATSIANA KULAKEVICH, PhD candidate, Department of Political Science, Rutgers, The State University of New Jersey, tatsiana.kulakevich@rutgers.edu

ALIAKSIEJ LASTOǓSKI, PhD in Sociology, Political Sphere Institute, Polack State University, lastowski18@gmail.com

ROMAN URBANOWICZ, MA student, Department of Sociology and Social Anthropology, Central European University, Budapest, urbanowicz_roman@ student.ceu.edu 